\title{
Metode Perkuatan Struktur Tangga
}

\author{
Miftahul Iman*1, Noerman Adi Prasetya ${ }^{2}$ \\ ${ }^{1,2}$ Universitas Borneo Tarakan, Jalan Amal Lama No. 01 Tarakan, Indonesia \\ ${ }^{3}$ Program Studi Teknik Sipil, FT UBT, Tarakan \\ e-mail: *anmifal@yahoo.com
}

Received 18 March 2021; Reviewed 19 March 2021; Accepted 25 August 2021

Journal Homepage: http://jurnal.borneo.ac.id/index.php/borneoengineering

\begin{abstract}
The damage to the stairs slab structure was often neglected. Repair efforts were limited to covering the surface of the damaged stair plate with cement paste. This study compared 2 methods of strengthening the stair plate structure in a row, namely the addition of reinforcement and strengthening of angled steel profiles. The case study in this research is the structure of the main staircase of the Faculty of Health Sciences (FIKES) building, University of Borneo Tarakan. This research used the analysis method of the bending moment equilibrium structure by evaluating the increase of the nominal moment capacity of the stair plate structure due to the strengthening of steel reinforcement and angled steel profiles. Based on the results of the performance evaluation study and the method of strengthening the reinforced concrete stair slab structure with the reinforcement method, it can be concluded that: (a) The results of the concrete quality check used a minimum concrete quality estimate of $17 \mathrm{MPa}$. (b) Based on the results of visual observation of the ladder structure at the edge of the structure, it is recommended not to use it because the thickness of the ladder plate is relatively thin and some reinforcement is visible. In addition, there are cracks that are large enough and extend on the landing plate. (c). The actual main stair structure was different from the preliminary design, it can be seen in the length of the ladder plate and the placement of the pedestal. (d) In general, the two reinforcement methods can increase the nominal moment capacity reduced by $40 \%$ to $60 \%$. (e) the reinforcement method with the addition of D10-150 steel reinforcement and the addition of a concrete blanket of $20 \mathrm{~mm}$ is relatively higher than the reinforcement method using the BJ37 L70x70x6 steel profile (10.98\%).
\end{abstract}

Keywords: Structure constrain; Structure reinforced; Momen capacity

\begin{abstract}
Abstrak
Kerusakan pada struktur pelat tangga seringkali diabaikan. Upaya perbaikan hanya sebatas menutupi permukaan pelat tangga yang rusak hanya dengan pasta semen. Penelitian ini membandingkan 2 buah metode perkuatan struktur pelat tangga berturut-turut yaitu penambahan tulangan dan perkuatan profil baja siku. Studi kasus dalam penelitian ini adalah struktur pelat tangga utama gedung Fakultas Ilmu Kesehatan (FIKES) Universitas Borneo Tarakan. Penelitian ini mengguanakan metode analisis struktur kesetimbangan momen lentur dengan cara mengevaluasi kenaikan kapasitas momen nominal struktur pelat akibat perkuataan dari tulangan baja dan profil baja siku. Berdasarkan hasil studi evaluasi kinerja dan metode perkuatan struktur pelat tangga beton bertulang dengan metode perkuatan, maka dapat diambil kesimpulan: (a) Hasil pemeriksan mutu beton digunakan estimasi mutu beton minimal yaitu 17 MPa. (b) Berdasarkan hasil pengamatan visual struktur tangga yang terdapat pada tepi struktur disarankan untuk tidak digunakan karena tebal pelat tangga relatif tipis dan terlihatnya beberapa tulangan. Selain itu terdapat retak yang cukup besar dan memanjang pada pelat bordes. (c). Struktur tangga utama aktual berbeda dengan perencanaan, hal itu dapat dilihat pada panjang pelat tangga dan perletakan tumpuan. (d) Secara umum kedua metode perkuatan dapat meningkatkan kapasitas momen nominal tereduksi $40 \%$ sampai dengan $60 \%$. (e) metode perkuatan dengan penambahan tulangan baja D10-150 dan penambahan selimut beton $20 \mathrm{~mm}$ relatif lebih tinggi daripada metode perkuatan menggunakan profil baja BJ37 L70x70x6 (10,98\%).
\end{abstract}

Kata kunci: Tumpuan struktur, Perkuatan struktur, Kapasitas momen 


\section{Pendahuluan}

Suatu struktur yang sudah mengalami beberapa penurunan kekuatan struktur yang salah satunya ditandai dengan adanya kerusakan berupa retak pada komponen struktural maupun non struktural, memerlukan suatu proses asesmen dan perbaikan perkuatan (Santosa dan Hartono, 2004), kemudian di dalam SNI 03-2847-2013 dan SNI 03-2847-2019 yang berturut-turut mengacu pada ACI Commite 318 (2011) dan ACI Commite 318 (2014) terdapat penjelasan apabila terdapat keraguan bahwa sebagian atau semua bagian suatu struktur memenuhi keamanan dari standar ini, evaluasi kekuatan harus dilakukan oleh insinyur professional bersertifikat, akan tetapi apabila pengaruh kekuatan telah dipahami dengan baik dan bila memungkinkan untuk mengukur dimensi dan sifat bahan yang diperlukan untuk analisis kekuatan berdasarkan pada pengukuran berarti syarat evaluasi tersebut mencukupi. Agustinus dan Lesmana (2019) mengatakan bahwa kerusakan pada bangunan disebabkan karena beberapa hal, di antaranya: salah perhitungan atau salah perencanaan awal, bencana alam, perubahan fungsi ruang, dan sebagainya. Langkah awal untuk memahami kondisi aktual di lapangan adalah mengetahui penyebab dan kekuatan sisa residual stress, maka diperlukan rangkaian metodologi pengamatan awal berupa visual investigation, dilanjutkan dengan investigasi detail dengan menggunakan pengujian non-destructive maupun semi destructive (Imran et. al, 2009).

Winarsih (2010) mengatakan bilamana suatu struktur beton setelah dilakukan re-analisis menunjukkan bahwa kekuatan nominal struktur atau elemen tidak cukup, dapat dilakukan improvisasi dengan berbagai teknik/variasi perkuatan (strengthening) dengan cara pembesaran penampang dan penambahan jumlah tulangan, pemberian lembaran metalic atau non-metalic, atau kombinasi kedua cara tersebut (Munaf, 2003). Memilih perkuatan pelat yang efektif memerlukan beberapa pertimbangan, antara lain: seberapa besar pengaruh perkuatan yang dilakukan, biaya perkuatan, waktu pekerjaan, dan metode pelaksanaan pekerjaan. Analisis struktur membutuhkan data lengkap, seperti dimensi pelat, tebal pelat, mutu beton, diameter tulangan, jenis tulangan, dan spasi antar tulangan yang mana untuk memperoleh data tersebut dibutuhkan investigasi dan uji lapangan. Setelah dilakukan analisis perkuatan pelat, lalu dilakukan analisis biaya perkuatan, waktu pekerjaan, dan metode pelaksanaan pekerjaan untuk mendapatkan jenis perkuatan yang efektif, hal ini sejalan dengan (Santosa dan Hartono, 2003) yang mengatakan untuk mendapatkan hasil perkuatan struktur beton yang optimal, maka harus dilakukan Investigasi, Evaluasi dan Pelaksanaan.

Tujuan penelitian adalah membandingkan antara perkuatan struktur pelat tangga menggunakan pembesaran penampang dan penambahan jumlah tulangan dan memperkecil bentang pelat dengan menggunakan profil baja balok IWF. Analisis penampang beton bertulangan tunggal yaitu dengan tulangan tarik saja didasarkan pada gambar 1 di bawah ini,

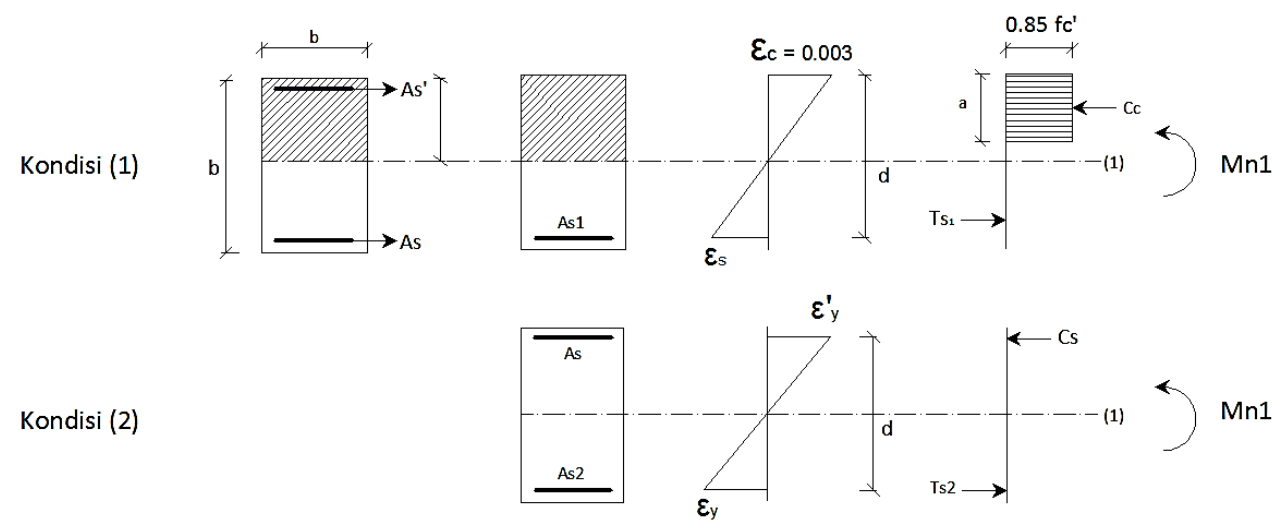

Gambar 1. diagram tegangan-regangan tulangan rangkap (Nawy, 1990) 


\section{Pada kondisi 1}

$$
\begin{aligned}
& T_{s}=T_{c} \\
& A_{S 1}<0,75 A_{S b} \\
& A_{S 1} \cdot f_{y}=0,85 \cdot f_{c}^{\prime} \cdot a \cdot b_{w} \\
& a=\frac{A_{S 1} \cdot f_{y}}{0.85 \cdot f_{c}^{\prime} \cdot b_{w}} \\
& M_{n 1}=T_{S} \cdot\left(d-\frac{a}{2}\right) \\
& M_{n 1}=A_{S 1} \cdot f_{y} \cdot\left(d-\frac{1}{2} \cdot \frac{A_{S 1} \cdot f_{y}}{0.85 \cdot f_{c}^{\prime} \cdot b_{w}}\right)
\end{aligned}
$$

dimana :

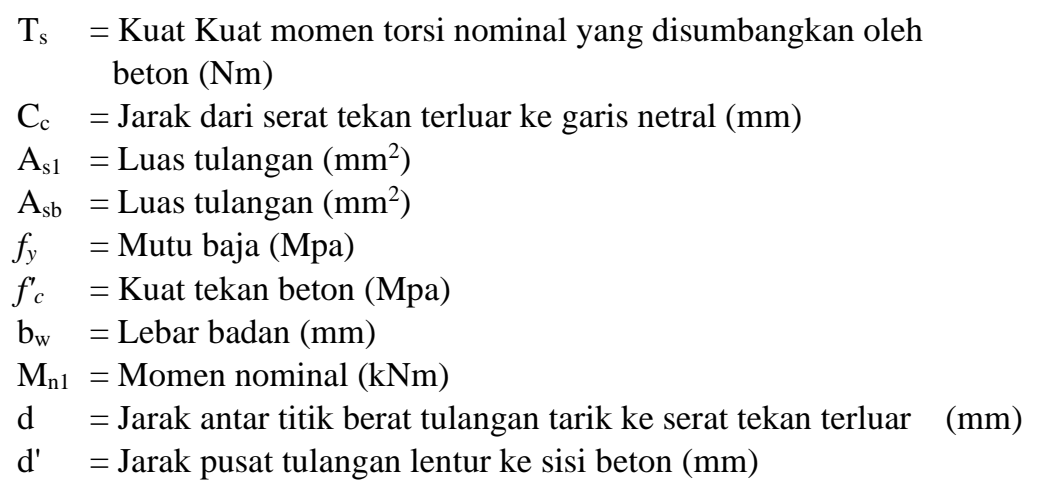

Selisih momen :

$$
\begin{aligned}
& M_{n 2}=T_{S 2} \cdot\left(d-d^{\prime}\right) \\
& M_{n 2}=\frac{M_{u}}{\phi} \cdot M_{n 1} \\
& f_{s 2}=f_{y} \\
& M_{n 2}=A_{S 2} \cdot f_{S 2} \cdot\left(d-d^{\prime}\right) \\
& A_{S}{ }^{\prime}=A_{S 2}=\left(\frac{M_{n 2}}{f_{S 2}\left(d-d^{\prime}\right.}\right)
\end{aligned}
$$

Sehingga diperoleh :

$$
\begin{array}{ll}
\text { Tulangan tarik } & : A_{s}=A_{s I}+A_{s 2} \\
\text { Tulangan tekan } & : A_{s^{\prime}}
\end{array}
$$

dimana :

$$
\begin{aligned}
& \mathrm{M}_{\mathrm{n} 2}=\text { Momen nominal }(\mathrm{kNm}) \\
& \mathrm{T}_{\mathrm{s} 2}=\text { Kuat momen torsi nominal yang disumbangkan oleh beton }(\mathrm{Nm}) \\
& \mathrm{Mu}=\text { Momen ultimit }(\mathrm{kNm}) \\
& \varnothing \quad=\text { Faktor reduksi kekuatan (tanpa satuan) } \\
& \mathrm{A}_{\mathrm{s} 1,2}=\text { Luas tulangan } 1,2\left(\mathrm{~mm}^{2}\right) \\
& \mathrm{A}_{\mathrm{s}} \quad=\text { Luas tulangan tekan }\left(\mathrm{mm}^{2}\right)
\end{aligned}
$$


SNI 28472013 menjelaskan adanya persyaratan mengenai komponen struktur penahan lentur (balok) yaitu sesuai dengan persamaan berikut 2.12

$$
A_{S \min }=\frac{\sqrt{f_{c}^{\prime}}}{4 f_{y}} b_{w} \cdot d
$$

Namun, nilai $A_{s \text { min }}$ tidak kurang dari $1,4 b_{w} d / f_{y}$

dimana :

$$
\begin{array}{ll}
A_{\text {smin }} & =\text { Luas tulangan minimal }(\mathrm{mm} 2) \\
f_{c} & =\text { Kuat tekan beton }(\mathrm{MPa}) \\
f y & =\text { Kuat leleh baja yang disyaratkan }(\mathrm{MPa}) \\
b w & =\text { lebar badan balok }(\mathrm{mm})
\end{array}
$$

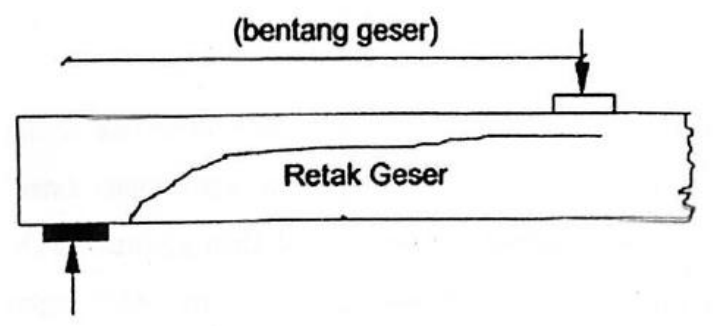

\section{Gambar 2. Tipikal kerusakan geser lentur (Nawy, 1998)}

Berdasarkan SNI 2847 2013, dasar perhitungan tulangan geser balok seperti Persamaan 2.13 berikut:

$$
V_{u} \leq \phi V_{n} ; \phi=0.75
$$

dimana :

$V_{n}=$ kuat geser nominal $(\mathrm{kN})$
$V_{n}=$ gaya geser terfaktor $(\mathrm{kN})$
$\varnothing=$ faktor reduksi

Sedangkan,

$$
V_{n}=V_{c}+V_{s}
$$

dimana :

$V_{c}=$ kuat geser nominal yang disumbangkan oleh beton $(\mathrm{kN})$

$V_{s}=$ kuat geser nominal yang disumbangkan oleh tulangan geser $(\mathrm{kN})$

Ketika proses desain yang dihitung yaitu jumlah tulangan geser yang diperlukan sehingga yang dicari adalah VS . BSN (2013) menjelaskan bahwa kuat geser VS tidak boleh melebihi kuat geser maksimum VS maks, yaitu dirumusakan pada Persamaan 2.15 sebagai berikut:

$$
V_{\text {Smaks }}=\frac{2 \sqrt{f_{c}^{\prime}}}{3} b_{w} \cdot d
$$

dimana :

$$
b_{w}=\text { lebar badan }(\mathrm{mm})
$$


$V_{\text {s maks }}=$ kekuatan geser sengkang $(\mathrm{kN})$

$d \quad=$ jarak dari serat tekan beton terluar ke titik berat tulangan $(\mathrm{mm})$

$f^{\prime}{ }_{c} \quad=$ kuat tekan beton $(\mathrm{MPa})$

Menurut BSN (2013) untuk komponen struktur non prategang yang hanya dibebani oleh geser dan lentur berlaku:

$$
V c=0.17 \lambda \sqrt{ } f c^{\prime} . b . d
$$

dimana $\lambda=1$ untuk penggunaan beton normal

Kekuatan geser sengkang dapat dihitung dengan menggunakan Persaman 2.17 hingga Persamaan 2.19 berikut,

$$
\begin{aligned}
& V_{S}=\frac{A_{v} \cdot f_{v} \cdot d}{s} \\
& S_{p e r l u}=\frac{A_{v} \cdot f_{v} \cdot d}{V_{s}} \\
& V_{r}=\phi\left(V_{s}+V_{c}\right)
\end{aligned}
$$

dimana:

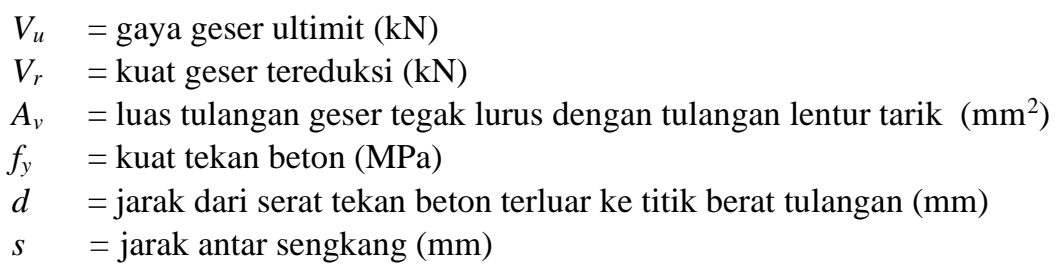

Nilai $A v$ tergantung pada berapa banyak sengkang yang tegak lurus (kaki tulangan) dengan tulangan lentur dikalikan dengan luas tulangan (As). Priyosulistyo (2010) menyebutkan bahwa hal gaya geser yang harus dipikul oleh sengkang harus memenuhi syarat sebagai berikut:

1. Jika $V s>4 V c$, maka yang diubah adalah dimensi balok

2. Jika $4 V c>V s>2 V c$, maka tulangan sengkang diperhitungkan dengan menggunakan persamaan (3.33) dengan jarak antara sengkang (s) memenuhi syarat $s<300 \mathrm{~mm}, s<$ $d / 4$.

3. Jika $2 V c>V s>V c$, maka tulangan sengkang diperhitungkan dengan menggunakan persamaan (3.33) dan jarak antara sengkang (5) memenuhi syarat : $s<600 \mathrm{~mm}$ dan $\mathrm{s}<$ $d / 2$.

4. Jika $V c>V s>0,5 V c$, maka luas tulangan sengkang minimum yang digunakan.

5. Jika $V u / \varnothing<0,5 V c$, maka tulangan sengkang tidak diperlukan.
a. $s<600 \mathrm{~mm}$,
b. $s<d / 2$.

Secara grafik syarat tulangan geser tersebut dapat dilihat pada Gambar 3 di bawah ini, 


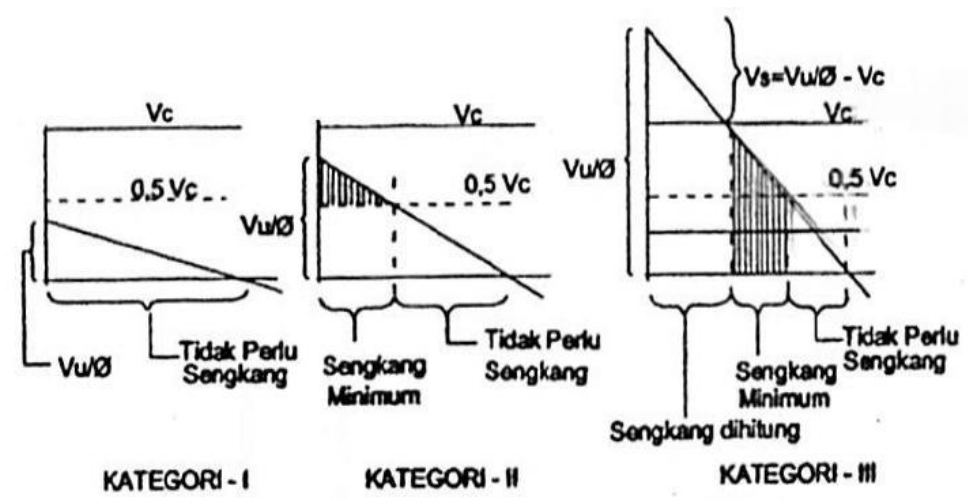

Gambar 3. Diagram Gaya Geser Balok (Priyosulistyo, 2010)

\section{Metode Penelitian}

Penelitian dilakukan di Laboratorium Teknik Sipil Universitas Borneo Tarakan dengan objek penelitian adalah Gedung Fakultas Ilmu Kesehatan Universitas Borneo Tarakan. Survei lapangan meliputi pengamatan secara visual (Visual Check), baik dengan mata telanjang maupun dengan bantuan kamera untuk melihat keretakan pada beton, serta melakukan investigasi cacat struktur yang lain seperti keropos, berlobang, mengelupas dan sebagainya. Kegiatan ini dilakukan terutama terhadap komponen yang berfungsi memikul beban-beban, baik beban vertikal maupun beban horizontal.

\subsection{Pengumpulan Data}

Pengumpulan data meliputi data primer dan data sekunder. Untuk data primer merupakan data yang langsung di ambil di lapangan berupa pengujian mutu bahan dengan cara non destructive test dengan Hammer Test berdasarkan SNI 03-4430-1997 dan Ultrasonic Pulse Velocitymeter (UPV) berdasarkan standar pengujian ASTM C597.
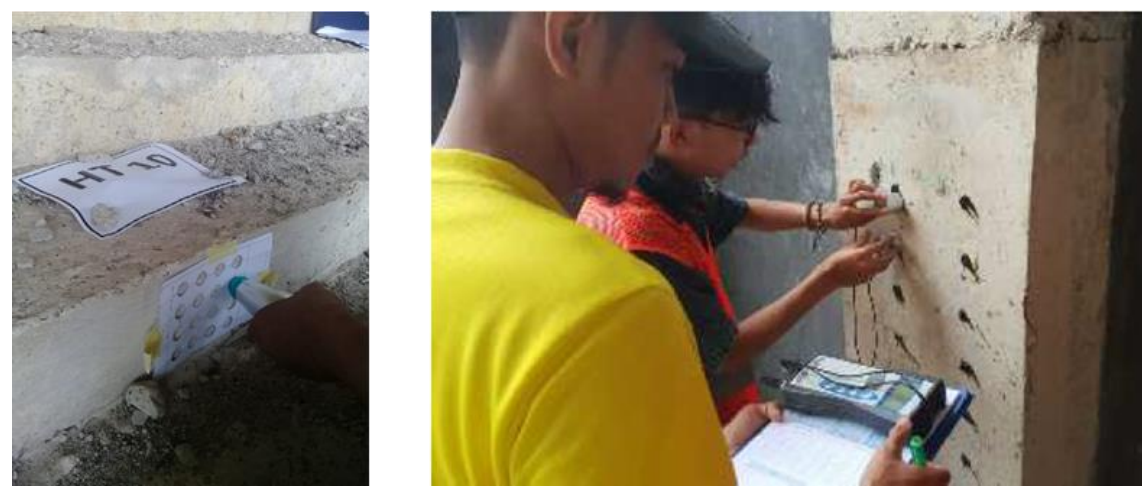

Gambar 4. Pengumpulan data mutu beton (undestructive test)

\subsection{Analisis struktur dan Evaluasi}

Hasil analisis struktur tangga utama dibedakan menjadi hasil analisis struktur tangga utama desain awal dan kondisi aktual (existing). 
Tabel 1. Tabulasi momen eksisting (awal)

$\begin{array}{lllll}\text { Nodal } & \text { M11 (kNm/m') } & \text { M22 (kNm/m') } & \begin{array}{c}\text { 0.8* Mn } \\ (\text { Kn-m/m) }\end{array} & \text { Mu }<\text { Mn }\end{array}$

\begin{tabular}{lcccc}
\hline 1 & 0,08 & 0,01 & & \\
2 & $-0,96$ & $-9,95$ & & \\
3 & 4,98 & 8,66 & 38,96 & Ok \\
4 & 3,66 & 3,44 & 38, & \\
5 & $-0,22$ & $-1,21$ & & \\
6 & 4,66 & 8,28 & & \\
7 & $-0,98$ & $-9,82$ & & \\
8 & 0,08 & 0,01 & & \\
\hline
\end{tabular}

Tabel 1 menunjukkan momen yang bekerja pada model tangga utama desain awal masih dalam kondisi belum aman. Hal tersebut ditunjukkan dengan tidak adanya nilai momen ultimit yang melebihi nilai momen nominal pelat tangga utama $(38,96 \mathrm{kNm} / \mathrm{m}$ ')
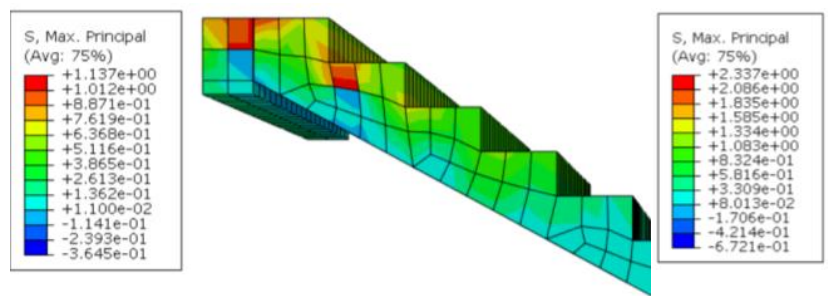

(a)

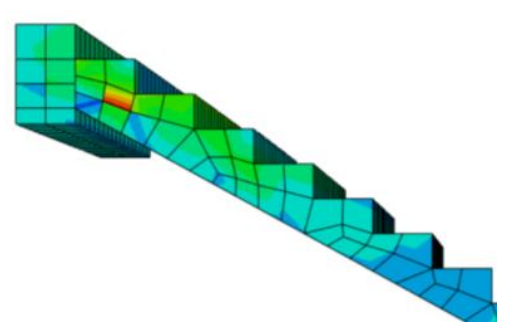

(b)

Gambar 5. Perbandingan kontur tegangan pelat-balok

Gambar 5 menunjukkan perbandingan kontur tegangan yang terjadi pada kondisi batas pelat tangga dan balok. Pada Gambar 5(a) menunjukkan bahwa elevasi anak tangga sama dengan elevasi pada balok 30/50. Kondisi ini menghasilkan tegangan maksimum (principle) $+1,137 \mathrm{MPa}$. Nilai tegangan masih berada di bawah nilai tegangan tarik yang diizinkan $\left(f^{\prime}{ }_{c}=20 \mathrm{MPa}\right)$.

Gambar 5(b) menunjukkan hubungan pelat tangga dan balok 30/50 brada pada elevasi $+4,825$. Kondisi hubungan seperti ini menghasilkan tegangan maksimum (principle) 2,337 MPa (51\%). Tegangan tarik yang dihasilkan telah melampaui tegangan ijin tarik beton. Konsekuensi dari situasi ini adalah munculnya retak pada daerah tegangan Tarik yang telah melampaui tegangan ijin tariknya.

\section{Hasil dan Pembahasan}

\section{Tipe kerusakan balok tangga}

Berdasarkan hasil investigasi di lapangan elemen balok menunjukkan terindikasi mengalami karbonasi. Beberapa elemen balok menunjukkan garis-garis berwarna kuning kecokelatan di daerah sisi tarik dan pada tampak samping balok seperti pada gambar 5 .

\section{Tipe kerusakan pelat tangga}

Berdasarkan hasil investigasi di lapangan dijumpai banyak kerusakan pada struktur tangga. Elemen struktur tangga banyak terdapat tumbuhan lumut pada sudut bordes dan beberapa anak tangga. Beberapa retak juga telah diidentifikasi seperti pada gambar 7 


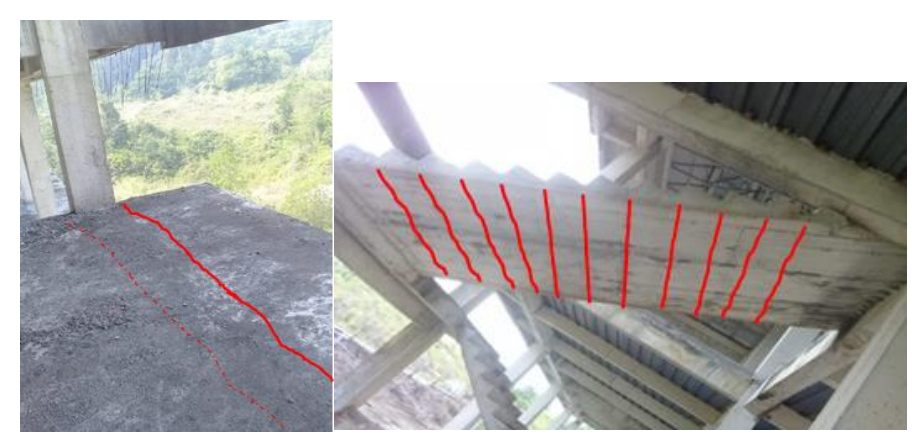

(a)

(b)

Gambar 7. Visual Check Struktur Tangga Gedung FIKES UBT

\section{Perbandingan hammer test dan UPV}

Perbandingan nilai perkiraan kuat tekan beton berdasarkan hammer test dan UPV test disajikan pada Tabel 4.5.

Tabel 2. Perbandingan hasil uji hammer dan UPV

\begin{tabular}{lcc}
\multicolumn{2}{c}{ Perkiraan mutu beton (Mpa) } & $\boldsymbol{\alpha}$ \\
Hammer & UPV & $(\boldsymbol{\%})$ \\
\hline 34,00 & 20,99 & 38,26 \\
30,00 & 19,55 & 34,85 \\
21,33 & 13,09 & 38,61 \\
31,99 & 14,87 & 53,54 \\
\hline
\end{tabular}

Berdasarkan hasil perbandingan perkiraan mutu beton antara hasil uji hammer dan UPV (CA = $1110,3 \mathrm{~kg} / \mathrm{m}^{3}, \mathrm{Al}-\mathrm{Nu}$ 'man dkk, 2015) terdapat perbedaan yang cukup signifikan dengan margin $(\alpha)$ berkisar antara $34,85 \%$ sampai dengan $53,54 \%$. Nilai perbedaan yang cukup besar ini sehingga kedua metode NDT tersebut tidak dapat memverifikasi satu dengan yang lainnya. Hal tersebut juga dapat disebabkan oleh kurangnya keterwakilan data (sampel), kalibrasi alat, dan metode pengujian.

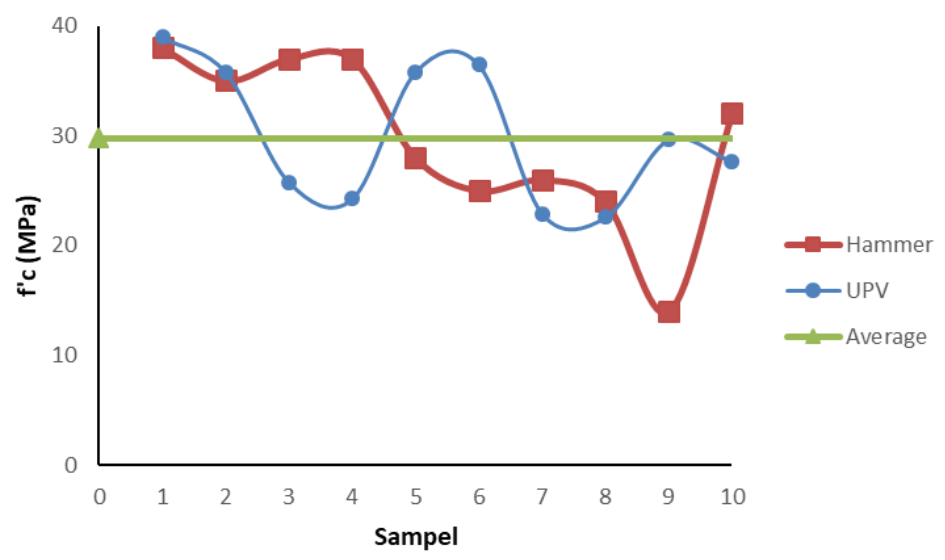

Gambar 8. Kurva perbadingan hasil uji mutu beton 
Perkiraan mutu beton hasil uji UPV lebih rendah dari hasil uji hammer (41,31\%). Nilai perkiraan mutu beton yang digunakan dalam kegiatan building assessment ini adalah nilai kuat tekan beton desain (20 MPa atau $250 \mathrm{~kg} / \mathrm{cm}^{2}$ ) dan nilai kuat desak minimal dari pengujian NDT (17 MPa atau $206 \mathrm{~kg} / \mathrm{cm}^{2}$ ). Berdasarkan Tabel 2 maka rerata perkiraan mutu beton adalah 353,42 kg/cm 2 atau 29 MPa (hammer test) dan $206 \mathrm{~kg} / \mathrm{cm}^{2}$ atau $17 \mathrm{MPa}$ (UPV).

\section{Analisis Struktur Tangga Utama}

Hasil analisis struktur tangga utama dibedakan menjadi hasil analisis struktur tangga utama desain awal dan kondisi aktual (existing).

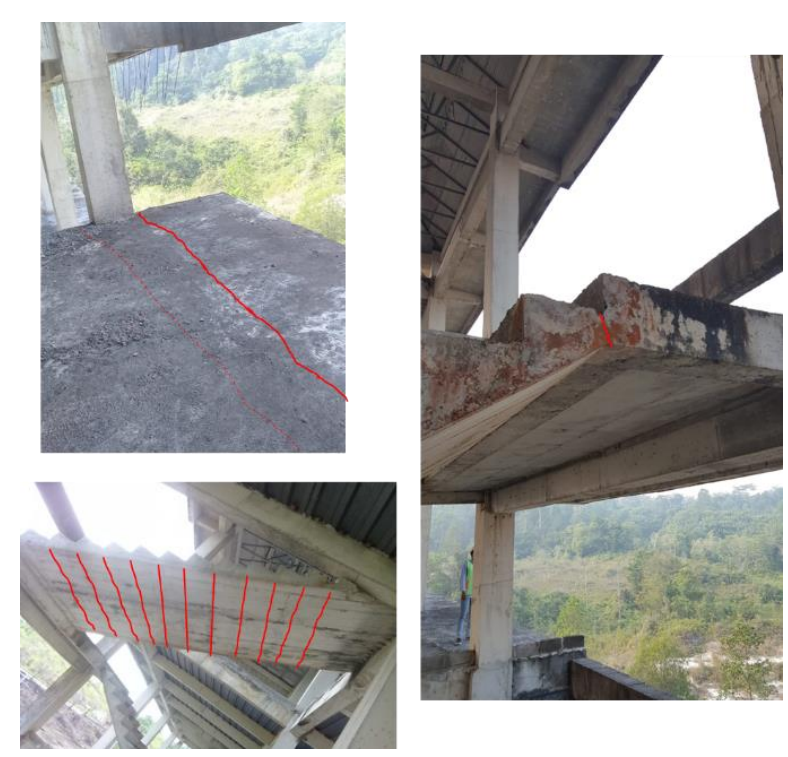

Gambar 9. Retak pada pelat tangga utama

Gambar 9 menunjukkan kesesuaian pola retak pelat tangga utama terhadap model numerik. Distribusi kontur momen dan kontur tegangan pada pelat bordes menimbulkan retak yang memanjang dekat tumpuan balok 30/50. Area 2 pada model 3D shell juga menunjukkan adanya tegangan yang berlebih dan menimbulkan retak pada anak tangga ke dua dari pelat bordes.

\section{Metode Perbaikan dan Perkuatan}

Berdasarkan hasil pengamatan, pengukuran, analisis dan pembahasan sebelumnya maka terdapat beberapa elemen-elemen struktur yang perlu direkomendasikan untuk dilakukan perbaikan. Elemen-elemen struktur tersebut terdiri dari:

\section{Metode perkuatan dengan penambahan tulangan}

Metode perkuatan struktur pelat tangga beton bertulang dilakukan dengan penambahan tulangan baja pada sisi tarik juga telah dilakukan. Tulangan baja ulir diameter $12 \mathrm{~mm}$ telah dipilih dalam penelitian ini. 


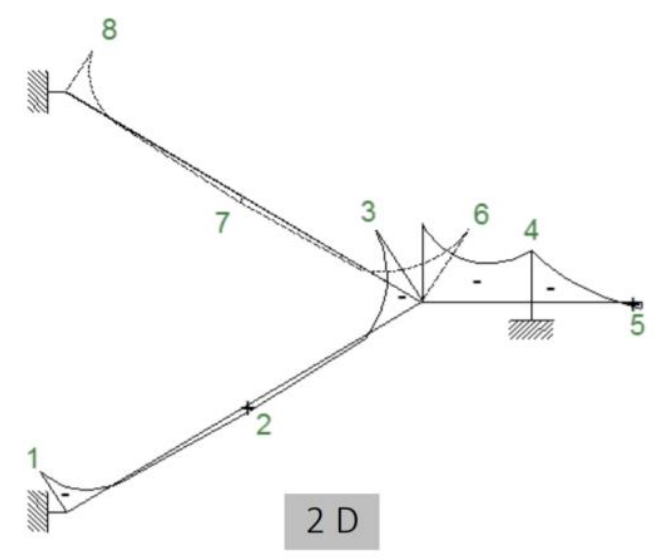

\section{Gambar 11. Momen pada struktur tangga}

Gambar 11 menunjukkan diagram momen lentur (BMD) pada struktur pelat yang ditinjau. Gambar 11 juga menunjukkan bahwa momen negatif lebih besar daripada momen positif. Momen negatif paling besar $(-20,28 \mathrm{kNm})$ terjadi pada daerah bordes peralihan tangga bawah menuju tangga atas.

Tabel 3. Tabulasi momen pada model aktual

\begin{tabular}{rcccc}
\hline Nodal & $\mathbf{M}_{\mathbf{1 1}}\left(\mathbf{k N m} / \mathbf{m}^{\prime}\right)$ & $\mathbf{M}_{\mathbf{2 2}}\left(\mathbf{k N m} / \mathbf{m}^{\prime}\right)$ & $\begin{array}{l}\mathbf{0 . 8} * \mathbf{M n} \\
(\mathbf{K n}-\mathbf{m} / \mathbf{m})\end{array}$ & $\mathbf{M u}<\mathbf{M n}$ \\
\hline 1 & 3.62 & 4.70 & & \\
2 & -0.97 & $-20,28$ & & \\
3 & 6.50 & 19,30 & & Ok \\
4 & 3.95 & 3,40 & $\mathbf{2 1 , 2 0}$ & \\
5 & -0.89 & $-1,65$ & & \\
6 & 6.26 & 18,84 & & \\
7 & -0.97 & $-20,05$ & & \\
8 & 3.47 & 4,70 & & \\
\hline
\end{tabular}

Tabel 3 menunjukkan bahwa terdapat beberapa momen ultimit $(-20,28)$ yang mendekati nilai $m$ momen nominal. Hal ini tidak baik untuk kondisi struktur tangga utama itu sendiri. Nilai margin antara momen ultimit dan momen nominal yang begitu dekat sangat beresiko, terutama mutu beton tidak dapat diketahui dengan baik.
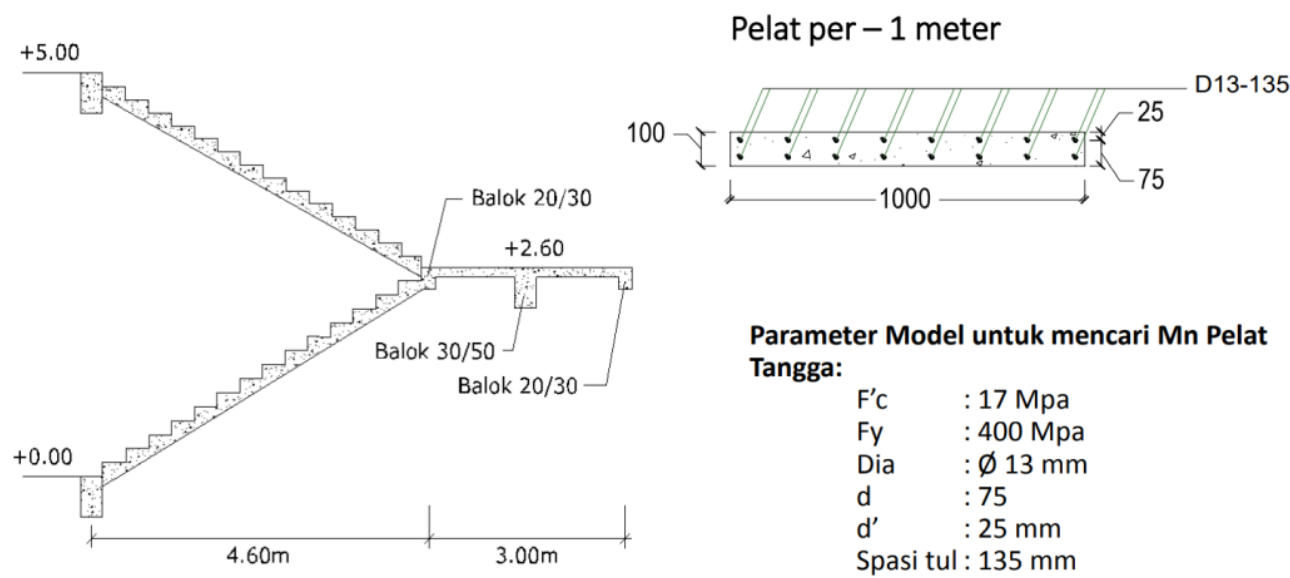

Parameter Model untuk mencari Mn Pelat Tangga:

$$
\begin{array}{ll}
\mathrm{F}^{\prime} \mathrm{c} & : 17 \mathrm{Mpa} \\
\mathrm{Fy} & : 400 \mathrm{Mpa} \\
\text { Dia } & : \varnothing 13 \mathrm{~mm} \\
\mathrm{~d} & : 75 \\
\mathrm{~d}^{\prime} & : 25 \mathrm{~mm} \\
\text { Spasi tul } & : 135 \mathrm{~mm}
\end{array}
$$

Gambar 12. Sistem penulangan struktur tangga eksisting 
Hasil analisis struktur pelat tangga eksiting menunjukkan bahwa kapasitas momen nominal $(\phi \mathrm{Mn})$ tangga < momen ultimit yang bekerja $(\mathrm{Mu})$. Persentase perbedaan kapasitas momen nominal yang telah direduksi terhadap momen terfaktor yang bekerja adalah 17,61\%. Hasil analisis struktur juga menunjukkan bahwa rendahnya kapasitas momen nominal struktur tang adalah akibat tebal pelat struktur tangga yang rendah $(h=100 \mathrm{~mm})$ dan jarak tulangan yang kurang dari persyaratan yang telah ditentukan (D13-100).

Metode perkuatan yang diberikan adalah penambahan tulangan tarik pada sisi bawah stuktur pelat tangga (sisi tarik) dan penambahan selimut beton. Tebal pelat tangga bertambah $10 \mathrm{~cm}$ sehingga menjadi $110 \mathrm{~cm}$. Penambahan tebal struktur pelat tangga mengakibatkan bertambahnya tinggi efektif $(d)$ menjadi $78,5 \mathrm{~mm}$. Diameter tulangan baja yang digunakan sebagai perkuatan adalah D13-135. Penempatan tulangan tambahan D13 diatur sedemikian rupa agar terletak di antara tulangan yang telah lama terpasang pada struktur pelat tangga eksisting (Gambar 4.22). Mutu beton tambahan tebal pelat lantai didesain K300 (f'c $=25 \mathrm{MPa}$ ).

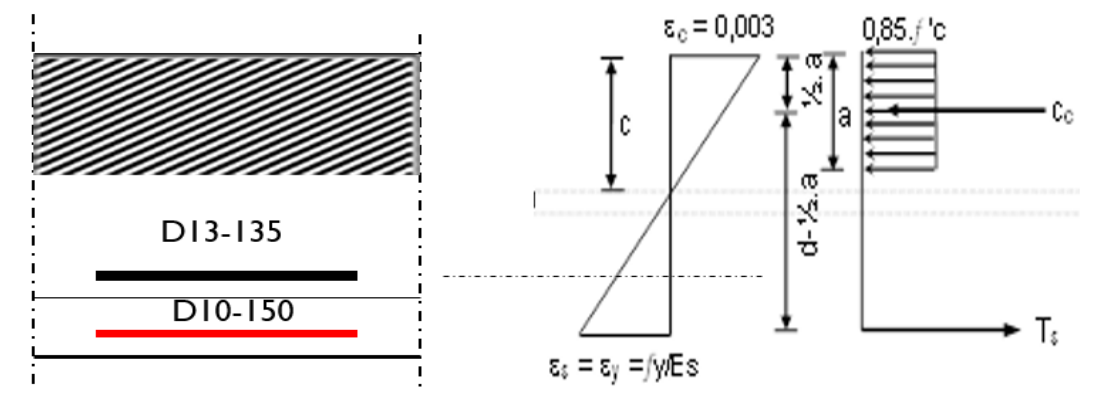

Gambar 13. Distribusi regangan dan tegangan beton perkuatan D10-150

Penambahan tulangan D10-150 mm pada sisi tarik struktur mengakibatkan beretambahnya jumlah tulangan tarik pada pelat yang semula adalah 8 butir tulangan menjadi 12 butir tulangan (4 butir tulangan D10-150) setiap $1 \mathrm{~m}$ lebar pelat tangga. Penambahan tulangan D10-150 tidak mengakibatkan struktur pelat tangga beton bertulang menjadi getas (brittle). Hal ini disebabkan oleh karena nilai a masih lebih kecil $\mathrm{a}_{\mathrm{b}}(40,26 \mathrm{~mm}<60)$ yang artinya adalah penulangan liat (ductile, underreinforced).

\subsubsection{Metode perkuatan dengan penambahan profil baja siku}

Metode perkuatan struktur pelat tangga beton bertulang dilakukan dengan penambahan profil baja BJ 37 siku 70x70x6 pada sisi tarik juga telah dilakukan. Properties geometrik disajikan dalam Tabel 4 di bawah ini.

Tabel 4. Propertis geometrik L70x70x6

\begin{tabular}{ccc}
\hline $\boldsymbol{A}\left(\mathbf{c m}^{\mathbf{2}}\right)$ & $\boldsymbol{t}(\mathbf{c m})$ & $\boldsymbol{w}(\mathbf{k g} / \mathbf{m})$ \\
\hline 8,13 & 6,00 & 6,38 \\
\hline
\end{tabular}

Profil baja siku L70x70x6 diletakkan pada arah memanjang struktur pelat tangga utama dapat dilihat pada Gambar 14 di bawah ini. 


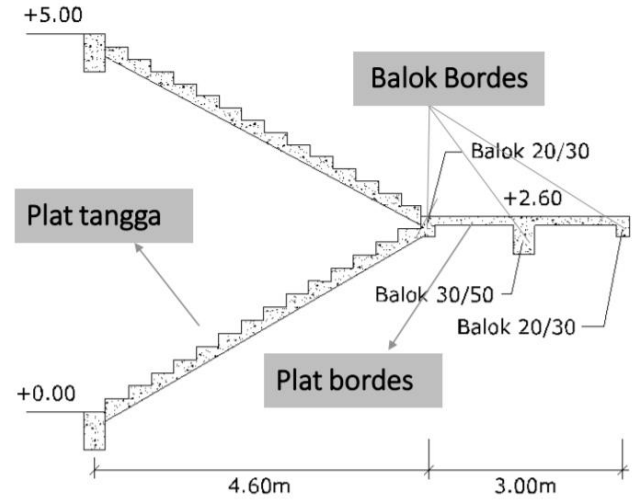

(a)

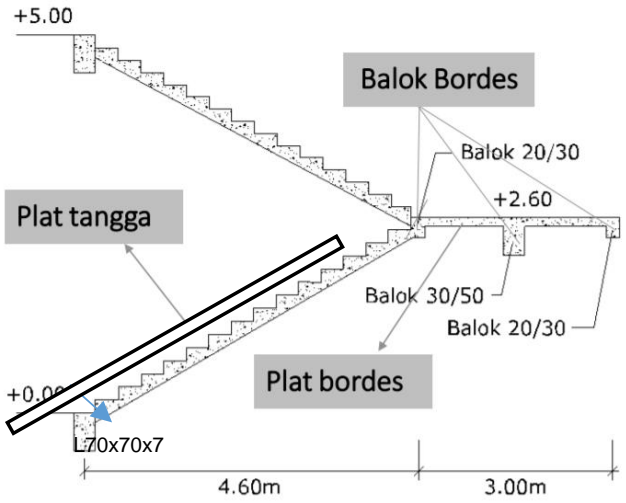

(b)

\section{Gambar 14. Perkuatan struktur tangga utama menggunakan profil L70x70x6}

Hasil analisis struktur sebelumnya menunjukkan kapasitas momen nominal yang telah direduksi $(\phi \mathrm{Mn})$ lebih kecil dari momen terfaktor $(\mathrm{Mu})$ yang berkejaa pada struktuy pelat tangga utama $(16,78 \mathrm{kNm}<20,37 \mathrm{kNm})$.
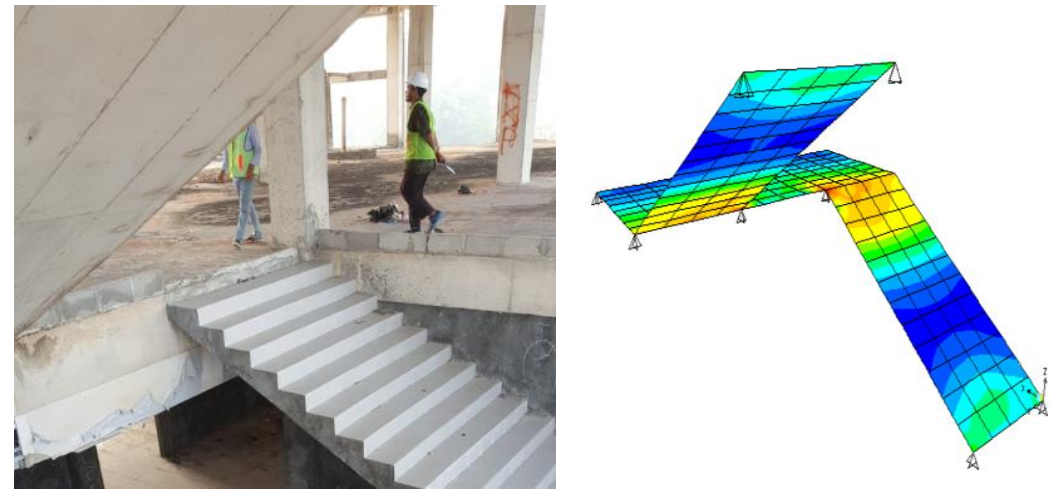

Gambar 15. Momen pada struktur tangga

Gambar 15 menunjukkan kontur momen lentur maksimum yang terdapat pada struktur pelat yang ditinjau. Gambar 15 juga menunjukkan pemodelan numerik struktur pelat tangga utama. Berdasarkan hasil numerik kontur momen maksimum positif terletak di tengah bentang (Tabel 5).

Tabel 5. Tabulasi momen pada model numerik

\begin{tabular}{|c|c|c|c|c|c|c|c|c|}
\hline Area & AreaElem & OutputCase & CaseType & M11 & M22 & M12 & MMax & MMin \\
\hline Text $\mathbf{v}$ & Text $\mathbf{\nabla}$ & \begin{tabular}{l|l} 
Text & $\nabla$
\end{tabular} & \begin{tabular}{l|l|} 
Text & $\nabla$ \\
\end{tabular} & $\mathrm{KN}-\mathrm{m} / \mathrm{n} \mathbf{v}$ & $\mathrm{KN}-\mathrm{m} / \mathrm{n} \nabla$ & $\mathrm{KN}-\mathrm{m} / \mathbf{v}$ & $\mathrm{KN}-\mathrm{m} / \mathrm{T}+$ & $\mathrm{KN}-\mathrm{m} / \mathrm{I}^{\mathrm{v}}$ \\
\hline 132 & 79 & $1,2 \mathrm{D}+1,6 \mathrm{~L}$ & Combination & 0,0319 & 26,6754 & 3,3105 & 27,0806 & $-0,3733$ \\
\hline 134 & 81 & $1,2 \mathrm{D}+1,6 \mathrm{~L}$ & Combination & 0,0387 & 26,7093 & 2,4688 & 26,9359 & $-0,187 \mathrm{c}$ \\
\hline 109 & 56 & $1,2 \mathrm{D}+1,6 \mathrm{~L}$ & Combination & 0,0313 & 26,6125 & $-1,2285$ & 26,6692 & $-0,0253$ \\
\hline 134 & 81 & $1,2 \mathrm{D}+1,6 \mathrm{~L}$ & Combination & 0,0331 & 26,5295 & 1,8638 & 26,6599 & $-0,0973$ \\
\hline 110 & 57 & $1,2 \mathrm{D}+1,6 \mathrm{~L}$ & Combination & 0,0386 & 26,649 & $-0,4003$ & 26,6551 &, 032 \\
\hline 86 & 33 & $1,2 \mathrm{D}+1,6 \mathrm{~L}$ & Combination & 0,0329 & 26,1811 & $-3,364$ & 26,607 & $-0,393$ \\
\hline 136 & 83 & $1,2 \mathrm{D}+1,6 \mathrm{~L}$ & Combination & 0,0377 & 26,5524 & 1,1539 & 26,6025 & $-0,0124$ \\
\hline 80 & 27 & $1,2 \mathrm{D}+1,6 \mathrm{~L}$ & Combination & 0,0394 & 26,214 & $-2,5167$ & 26,4538 & $-0,2004$ \\
\hline 111 & 58 & $1,2 \mathrm{D}+1,6 \mathrm{~L}$ & Combination & 0,0389 & 26,4096 & 0,8642 & 26,4379 & 0,0107 \\
\hline 110 & 57 & $1,2 \mathrm{D}+1,6 \mathrm{~L}$ & Combination & 0,0332 & 26,381 & 0,1847 & 26,3823 & 0,0319 \\
\hline
\end{tabular}

Tabel 5 menunjukkan bahwa momen lentur maksimum $(\mathrm{Mu}=26,68 \mathrm{kNm})$ yang lebih besar dari nilai kapasitas momen nominal yang dimiliki oleh struktur pelat tangga beton bertulang tidak aman 
bahkan apabila mutu beton ditingkatkan menjadi $25 \mathrm{MPa}$. Hal ini tentu saja telah membuat struktur pelat tangga beton bertulang itu sendiri memiliki tingkat kerawanan yang sangat tinggi terlebih lagi struktur pelat tangga tersebut merupakan elemen struktur dari gedung kampus dengan kapasitas beban hidup yang cukup besar.

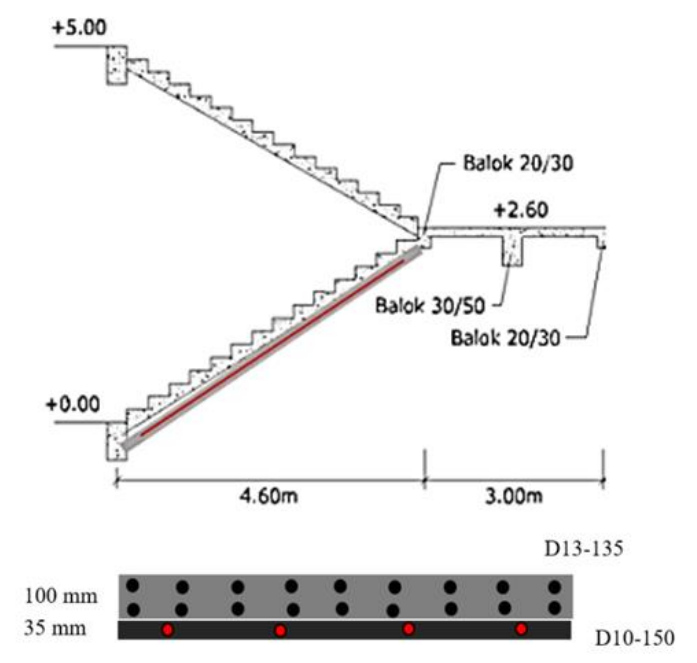

\section{Gambar 16. Momen pada struktur tangga}

Gambar 17 menunjukkan penggunaan baja BJ37 profil L70x70x7 sebagai perkuatan struktur pelat tangga. Profil L70x70x7 juga dilengkapi tulangan baja (P10-200). Tulangan baja difungsikan hanya untuk meningkatkan kekakuan struktur pelat tangga secara umum dan profil L70x70x6 khususnya sebagai antisipasi lentur arah lateral (M22) .

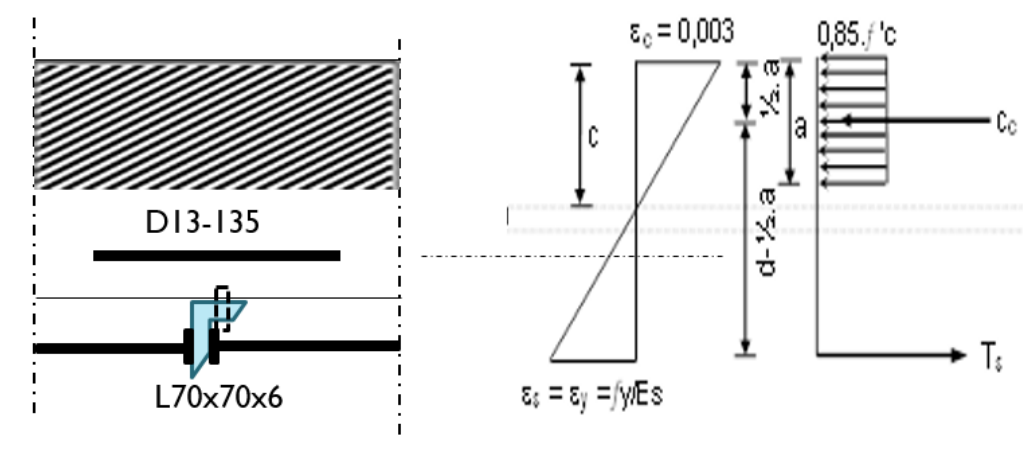

\section{Gambar 17. Distribusi regangan dan tegangan perkuatan L70x70x6}

Berdasarkan hasil analisis struktur pelat tangga utama dengan perkuatan profil L70x70x6 diperoleh kenaikan kapasitas momen nominal yang telah direduksi ( $\phi M n)$ sebesar 49,29\%. Hasil analisis juga menunjukkan bahwa blok tekan terjadi pada profil L70x70x7 (Gambar 18).

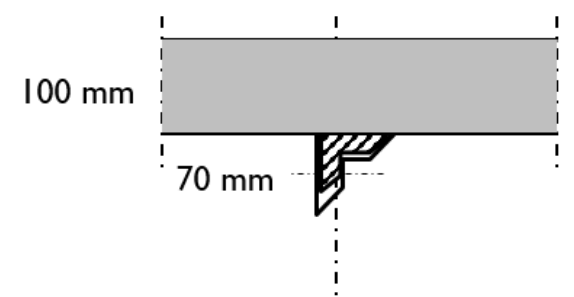

Gambar 18. Blok tekan pada profil L70x70x6 
Gambar 18 juga menunjukkan bahwa nilai a $(108,03 \mathrm{~mm})>$ dari tebal pelat $(100 \mathrm{~mm})$. Kapasitas momen nominal yang direduksi $(\phi \mathrm{Mn})$ akibat perkuatan profil L70x70x6 BJ 37 dapat dihitung $(33,09 \mathrm{kNm})$. Nilai tersebut masih relatif aman terhadap momen terfaktor yang bekerja.

\subsubsection{Perbandingan metode perkuatan}

Secara umum kedua metode perkuatan memiliki daya perkuatan yang relatif tinggi (40\% sampai dengan 60\%) terhadap kapasitas momen nominal reduksi awal (sebelum diberi perkuatan).
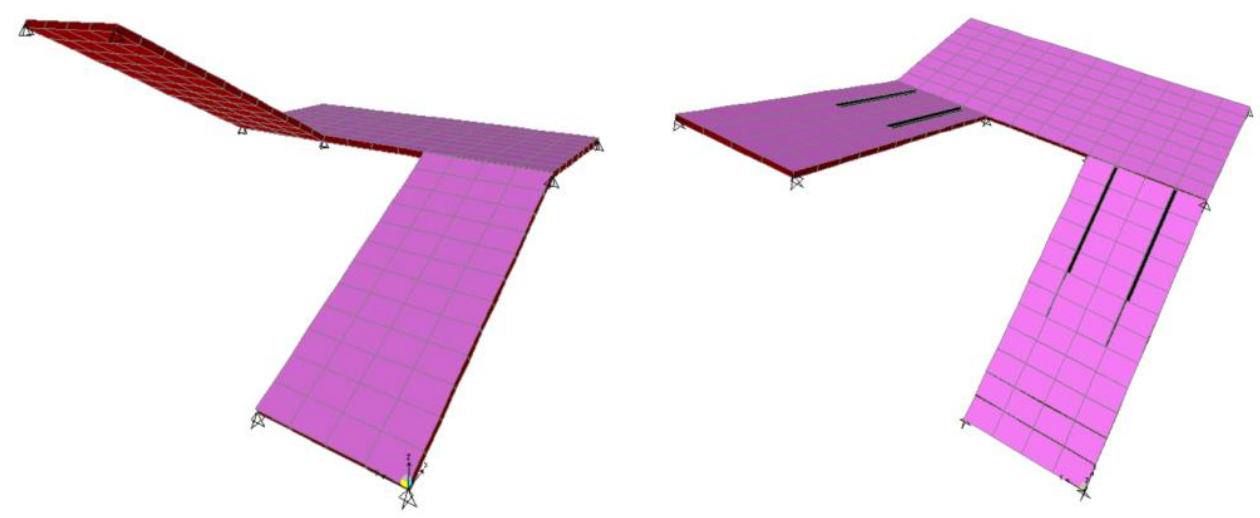

Gambar 19. Perbandingan metode perkuatan (model numerik)

Setiap metode perkuatan memiliki keunggulan dan kelemahan masing-masing. Hasil penelitian menunjukkan bahwa perkuatan struktur pelat tangga menggunakan tulangan baja tambahan (D10150) dan tebal selimut beton $(20 \mathrm{~mm})$ memiliki peningkatan kapasitas momen nominal yang direduksi yang relatif lebih tinggi dibandingkan dengan kapasitas momen nominal tereduksi berdasarkan hasil perkuatan dengan baja 37 profil L70x70x6.

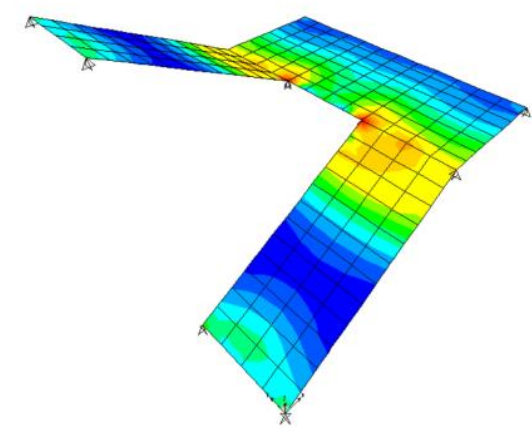

(a)

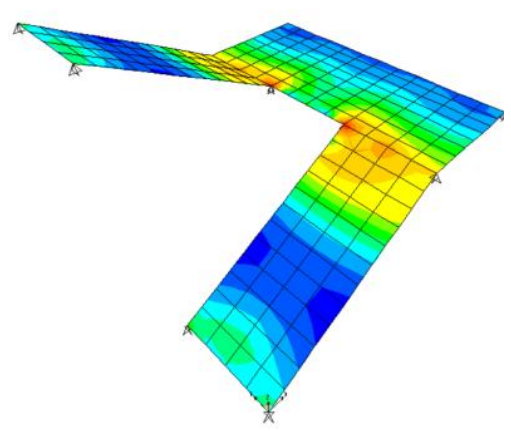

(b)

Gambar 20. Perbandingan kontur momen lentur

Gambar 20 menunjukkan perbedaan kontur momen lentur yang terjadi pada tengah bentang struktur pelat tangga dengan metode perkuatan yang berbeda. Momen lentur terfaktor pada model struktur pelat tangga dengan perkuatan profil baja L70x70x6 (gambar 20(b)) relatif lebih rendah dibandingkan dengan perkuatan struktur pelat tangga menggunakan penambahan tulangan baja D10-150 dan penambahan tebal selimut beton $(20 \mathrm{~mm})$ yang ditunjukkan pada Gambar 20 (a). 


\section{Kesimpulan}

Berdasarkan hasil studi evaluasi kinerja dan metode perkuatan struktur pelat tangga beton bertulang dengan studi kasus pada Gedung FIKES UBT diperoleh kesimpulan bahwa metode perkuatan dengan penambahan tulangan baja D10-150 ditambah selimut beton $20 \mathrm{~mm}$ atau perkuatan menggunakan profil baja BJ37 L70x70x6 dapat meningkatkan kapasitas momen nominal tereduksi menjadi $40 \%$ sampai dengan $60 \%$, serta perkuatan dari penambahan tulangan relatif lebih tinggi daripada penambahan profil siku.

\section{Daftar Pustaka}

ACI Commite 318 (2011): Building Code Requirements for Structural Concrete and Commentary (ACI 318-11), American Concrete Institute.

ACI Commite 318 (2014): Building Code Requirements for Structural Concrete and Commentary (ACI 318-14), American Concrete Institute.

Agustinus, S dan Lesmana, C, 2019, Perbandingan Analisis Perkuatan struktur Pelat dengan Metode Elemen Hingga, Vol 15 No1,

https://garuda.ristekbrin.go.id/documents/detail/1273625

Hartono dan Hari Santoso, Perkuatan Struktur Beton Dengan FRP, Concrete Repair \& Maintenance, Jakarta, Yayasan John Hi-tech Iditama, Edisi pertama, 2003.

Imran, S. Darmawan, I. Sulaiman, C. Lie, Aryantho, Assessment and Repair / Strengthtening of a Settlement Damaged Office Building, Proceeding of 1st International Conference on Rehabilitation and Maintenance in Civil Engineering (ICRMCE), Solo, Maret 2009.

Priyosulistyo, H., 2010. Perancangan Analisis Struktur Beton Bertulang I. Yogyakarta: Biro Penerbit Teknik Sipil UGM.

Munaf, D.R. dkk, Diagnosa dan perbaikan untuk peningkatan Kinerja struktur Beton, Concrete Repair \& Maintenance, Jakarta, Yayasan John Hi-tech Iditama, Edisi pertama, 2003.

Nawy, E. G, Bambang Suryoatmono, Beton Bertulang Suatu Pendekatan Dasar, Bandung, Eresco, 1990.

Nawy, E. G. (alih bahasa: Bambang Suryoatmono), Beton Bertulang Suatu Pendekatan Dasar, Bandung, PT. Refika Aditama, 1998.

SNI 03-2847-2013, Tata Cara Perhitungan Struktur Beton untuk Bangunan Gedung, Perhitungan Struktur Beton untuk Banguan Gedung, Jakarta, 2013.

SNI 03-2847-2019, Tata Cara Perhitungan Struktur Beton untuk Bangunan Gedung, Perhitungan Struktur Beton untuk Banguan Gedung, Jakarta, 2002.

Winarsih, T, 2010, Asesmen Kekuatan Struktur Bangunan Gedung Studi Kasus: Bangunan Gedung UGD dan Administrasi RSUD Banyudono Kabupaten Boyolali, Tesis untuk derajat Magister Teknik Struktur, Universitas Sebelas Maret (tidak dipublikasikan). 
